Scientific Electronic Archives

Issue ID: Sci. Elec. Arch. Vol. 14 (11)

November 2021

DOI: http://dx.doi.org/10.36560/141120211458

Article link: https://sea.ufr.edu.br/SEA/article/view/1458

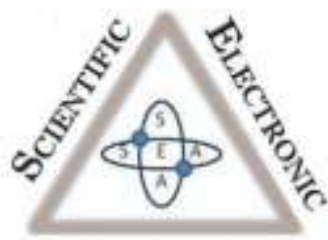

Archives

ISSN 2316-9281

\title{
Productivity and quality of watermelon fruits as a function of doses potassium in the Western Amazon
}

Francisco de Assis Menezes

Universidade Federal de Rondônia

Corresponding author

Reginaldo Almeida Andrade

Universidade Federal de Rondônia

reginaldo.andrade@unir.br

Anderson Cristian Bergamin

Universidade Federal de Rondônia

Andressa Gregolin Moreira

Faculdade Marechal Rondon

Fabio Régis de Souza

Universidade Federal de Rondônia

\begin{abstract}
Potassium is the nutrient most demanded by watermelon, performing various physiological and biochemical functions, and its availability in the soil influences the production and quality of fruits. However, there is no recommendation for specific fertilization for the state of Rondônia, which has limited the production and quality of the harvested fruits. The objective of this work was to evaluate the effects of potassium doses on the productivity and quality of watermelon fruits, cultivar Crimson Sweet, in southern Western Amazonia. The experiment was carried out at the Federal University of Rondônia, in the municipality of Rolim de Moura, in an experimental design in randomized blocks, with five treatments and four replications. The treatments were doses 0 (control), 50, 100, 150 and $200 \mathrm{~kg} \mathrm{ha}^{-1}$ of $\mathrm{K}_{2} \mathrm{O}$. The variables analyzed were fruit mass, longitudinal and transverse diameter of fruits, number of fruits per plant, soluble solids content, exocarp thickness and productivity. Potassium doses did not influence the mean mass and longitudinal and transverse diameter of the fruits. The number of fruits per plant increased linearly as a function of the potassium doses applied, and with $157 \mathrm{~kg} \mathrm{ha}^{-1}$ of $\mathrm{K}_{2} \mathrm{O}$ the highest values of ${ }^{\circ}$ Brix were obtained. The dose of $147.2 \mathrm{~kg} \mathrm{ha}^{-1}$ of $\mathrm{K}_{2} \mathrm{O}$ promotes yields $61.6 \%$ above the national average and $82 \%$ above the state average.

Keywords: Citrullus lanatus, Potassium Fertilization, Fruit Quality
\end{abstract}

\section{Introduction}

The watermelon, Citrullus lanatus (Thunb.) Mansf., Cucurbitaceae family, is a species native to the African continent widely disseminated and cultivated in tropical and subtropical regions (Komane et al., 2017). In 2018, about 3.2 million hectares of watermelon were grown worldwide, with 103 million tons harvested, representing $12 \%$ of the world's fruit production (FAOSTAT, 2018).

Due to its rusticity, low capital investment and rapid financial return, its cultivation is carried out in all Brazilian regions, mainly by family farmers (Dias \& Resende, 2010). In 2019, Brazil produced about 2.3 million tons of watermelon, reaching an average productivity of $23.13 \mathrm{tha}^{-1}$ (IBGE, 2019). In the state of Rondônia, the areas destined for watermelon planting have been expanded in recent years, and although the state presents edaphoclimatic conditions appropriate to its cultivation (Souza, 2008), the local productivity, $19.95 \mathrm{t} \mathrm{ha}^{-1}$, is relatively low when compared to the main producing states, such as Goiás, Pernambuco and São Paulo with 41.06, 27.8 and $27.4 \mathrm{t} \mathrm{ha}^{-1}$ respectively (IBGE, 2019).

This fact may be associated with inadequate soil management, use of un adapted cultivars, deficient fertilization and absence of technical manuals with specific fertilization recommendations for the region, limiting the productivity and quality of harvested fruits (Barros et al., 2012). During its phenological cycle, the plant extracts large amounts 
of nutrients from the soil, $\mathrm{K}>\mathrm{N}>\mathrm{Ca}>\mathrm{Mg}>\mathrm{P}>\mathrm{S}$ (Grangeiro \& Cecílio Filho, 2005), so the adoption of nutritional replacement technologies is essential for successful production, especially in the Amazon region, where natural fertility and soil matter content sit low.

Potassium is the most demanded nutrient during watermelon cultivation (Grangeiro \& Cecílio Filho, 2005), and participates in various metabolic and biochemical processes of the plant, as in the activation of enzymes involved in respiration and photosynthesis, control of the opening and closing of stomata (Gurgel et al., 2010), production and translocation of sugars, starch synthesis (Kumar et al., 2007), besides influencing the color, size, acidity, nutritional value, peel thickness and resistance to transport and storage of fruits (Raij, 1990).

Considering that there is little information on soil management and fertilization strategies for watermelon cultivation in the Amazon biome, and that this activity has been expanding in the state of Rondônia, the objective was to evaluate the effects of the application of potassium doses on the productivity and quality of watermelon fruits in southern Western Amazonia.

\section{Material and methods}

The experiment was conducted in the experimental field of the Federal University of Rondônia, municipality of Rolim de Moura-RO, between April and July 2016. According to Köppen classification, the climate in the region is type Am, tropical monsoon (Alvares et al., 2013), with an average temperature of $26^{\circ} \mathrm{C}$ and average annual rainfall ranges from 1,900 to $2,200 \mathrm{~mm}$. The monthly average temperature and precipitation data that occurred during the experiment are shown in Figure 1.

The soil of the cultivation area was classified as Latossolo Vermelho-Amarelo distrófico (Oxisol) (Santos et al., 2018), with 53\% sand, $8.9 \%$ silt and $38.1 \%$ clay. Three months before the experiment, soil samples from the $0.0-0.20 \mathrm{~m}$ layer were collected and analyzed, revealing the following results: $\mathrm{pH}$ in water $=4.7 ; \mathrm{P}=3.7 \mathrm{mg} \mathrm{dm}^{-3} ; \mathrm{K}=0.26$ $\mathrm{cmol}_{\mathrm{c}} \mathrm{dm}^{-3} ; \mathrm{Ca}=4.1 \mathrm{cmol}_{\mathrm{c}} \mathrm{dm}^{-3} ; \mathrm{Mg}=1.4 \mathrm{cmol}_{\mathrm{c}} \mathrm{dm}^{-}$ 3. $\mathrm{Al}=0.12 \mathrm{cmol}_{\mathrm{c}} \mathrm{dm}^{-3} ; \mathrm{CTC}=5.8 \mathrm{cmol}_{\mathrm{c}} \mathrm{dm}^{-3}$; base saturation $=54 \%$ and $\mathrm{Mo}=30.1 \mathrm{~g} \mathrm{~kg}^{-1}$.

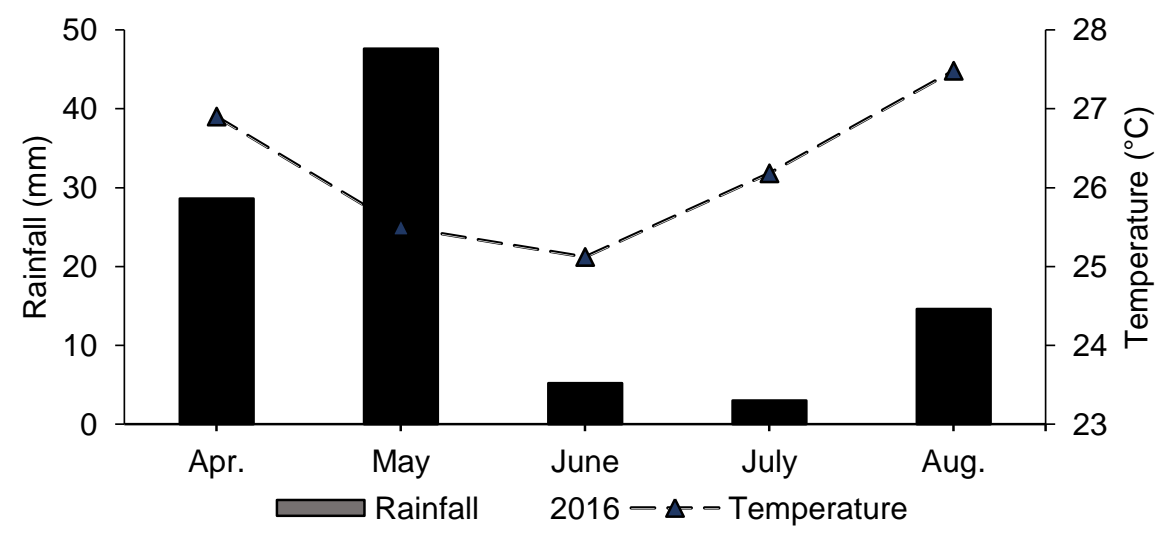

Figure 1. Average monthly temperature and precipitation occurred between June and August 2016 in the municipality of Rolim de Moura, Rondônia, Brazil.

The experimental design was randomized with five treatments and four replicates. The treatments consisted of doses of $0,50,100,150$ and $200 \mathrm{~kg} \mathrm{ha}^{-1}$ of $\mathrm{K}_{2} \mathrm{O}$ applied in the form of potassium chloride $\left(60 \%\right.$ of $\left.\mathrm{K}_{2} \mathrm{O}\right)$. Fertilizer application was divided at $15,30,45$ and 60 days after emergence (DAE), with $25 \%$ of the dose in each application.

The tillage was carried out conventionally, with a plowing followed by a leveling grid, twenty days before the opening of the planting holes, whose dimensions were $0.30 \times 0.30 \times 0.25 \mathrm{~m}$. Twenty days before sowing, organic fertilization was performed, with aviary bed, at a dose of $4.000 \mathrm{~kg}$ $\mathrm{ha}^{-1}$.

The planting spacing was $2.0 \mathrm{~m}$ between rows and $2.5 \mathrm{~m}$ between plants, with 16 plants per plot, where each plot had $45 \mathrm{~m}^{2}$. The seeds used were from the watermelon Crimson Select Plus ${ }^{\circledR}$ cultivar, of open pollination, and the sowing was carried out directly in the field, with three seeds per planting holes, with thinning at $15 \mathrm{DAE}$, leaving only one plant.

At the time of sowing, phosphate fertilization was performed, with $220 \mathrm{~kg} \mathrm{ha}^{-1}$ of $\mathrm{P}_{2} \mathrm{O}_{5}$ in the form of triple superphosphate. Nitrogen was applied in the form of urea, at a dose of $40 \mathrm{~kg}$ of $\mathrm{N} \mathrm{ha}^{-1,}$ performed in cover, at the same times of potassium fertilization. To meet the nutritional requirements of calcium and boron, additional applications were performed with CaBplus $^{\circledR}$ (2\% boron and $8 \%$ calcium), performed weekly through leaf applications, according to the recommendations of Ribeiro et al. (1999).

Weed control, sprayings and cover fertilization were always performed in the late afternoon, so as not to interfere in the process of pollination of flowers. To preserve the physical quality of the fruits, these were protected with dry 
straw from Urochloa brizantha, avoiding backrest spot, necrosis of the fruit peel, as well as possible scalding caused by the exposure of the fruits to the sun. The irrigation system used was by drip, with variable water depth according to the phenological stage of the plant, according to the guidelines of Souza et al. (2008) for watermelon cultivation in the state of Rondônia.

The harvest and evaluation of the quality of the fruits was carried out when the plants presented the tendril dry (organ of fixation of certain plants) located in the same node of the fruit. The variables analyzed were: number of fruits per plant; average fruit weight; longitudinal and transversal diameter of the fruit, measured with the aid of a graduated measuring tape; total soluble solids content (Brix), determined in extremity, near the exocarp, in intermediate region and central region of the fruit, using a digital refractometer; exocarp thickness ( $\mathrm{mm}$ ) and total productivity ( $\left.\mathrm{t} \mathrm{ha}^{-1}\right)$.

The data set was subjected to the assumptions of analysis of variance and when significant, regression analysis was adjusted to $5 \%$ probability.

\section{Results and discussion}

There was no effect $(p>0.05)$ of potassium doses on mean mass and longitudinal and transversal diameter of watermelon fruits. However, potassium doses influenced the number of fruits per plant in a linear way, and the smallest number of fruits was obtained in the control treatment, without $\mathrm{K}_{2} \mathrm{O}$ application, with 1.77 fruits per plant. At the highest dose, $200 \mathrm{~kg} \mathrm{ha}^{-1}$ of $\mathrm{K}_{2} \mathrm{O}$, there was an increase of $37 \%$, producing 2.42 fruits per plant, that is, the rate of increase was 0.0033 fruits for each $\mathrm{kg}$ of $\mathrm{K}_{2} \mathrm{O}$ applied to the soil (Figure 2).

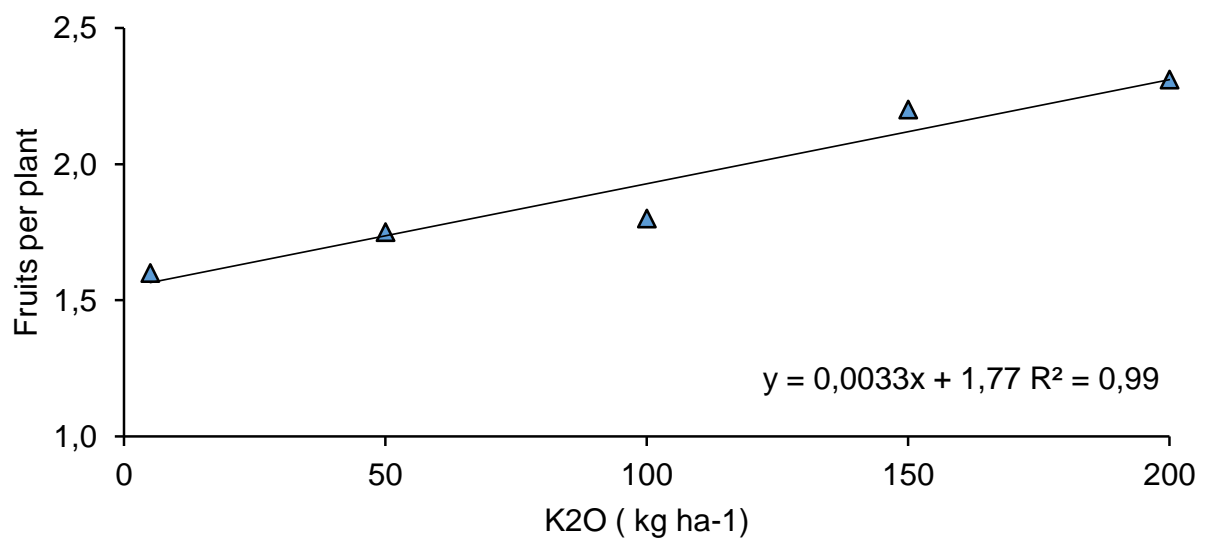

Figure 2. Number of fruits per watermelon plant as a function of potassium doses.

The increase in the number of fruits per plant is associated with greater fruit set, as potassium deficiency causes delay in floral opening and increased incidence of aborted flowers (Mengel \& Kirkby, 2001). The contents of total soluble solids (Brix) as a function of potassium doses, in the three regions of the analyzed fruit, can be explained by polynomial quadratic models (Figure 3 ). The ${ }^{\circ}$ Brix evaluated at the extremity close to the exocarp reached a maximum value with the application of $135.83 \mathrm{~kg}$ of $\mathrm{K} 2 \mathrm{O}$ ha- 1. In the intermediate region, the maximum ${ }^{\circ}$ Brix of the fruits was 10.75 when the dose $173.14 \mathrm{~kg}$ of K2O ha-1 was used. In the central region, the ${ }^{\circ} \mathrm{Brix}$ contents ranged from 9.52 (0 kg ha-1 of K2O) to 11.48 (161.87 kg ha- 1 of K2O) providing a sweeter and more pleasant flavor in the central area of the fruit.

The results observed for soluble solids contents in the central region are in the range considered ideal (between 10 and $13 \%$ ) for watermelon (Bleinroth, 1994). The increase in ${ }^{\circ}$ Brix, due to potassium fertilization, can be explained by the increase in the translocation of photoassimilates between the various organs, sources and drains of the plant, increasing the concentrations of sugars in the fruit (Taiz \& Zeiger, 2013), a fact already observed by Silva et al. (2014) for melon culture, Cucurbitaceae with nutritional requirements similar to watermelon. Meanwhile, Silva et al. (2015) evaluating the influence of nitrogen and potassium fertilization on the production components and total soluble solids contents of watermelon fruits, observed that the application of potassium doses ranging from 0 to $200 \mathrm{~kg} \mathrm{ha}^{-1}$ of $\mathrm{K}_{2} \mathrm{O}$ by did not promote difference in fruit quality.

The thickness of the bark decreased linearly with the increase of potassium doses, ranging from 1.72 to $1.42 \mathrm{~cm}$ (Figure 4). The thickness of the bark is an important physical characteristic, as it confers greater or lesser mechanical resistance, especially at the time of loading and transport of the fruits, since thinner shells have lower resistance to transport, while thicker shells reduce damage during post-harvest (Barros et al., 2012).

Watermelon productivity varied as a function of potassium doses applied, with quadratic adjustment for regression equation (Figure 5). The lowest productivity observed was $22.54 \mathrm{t} \mathrm{ha}^{-1}$ when potassium fertilization was not performed. The maximum yield obtained was $35.56 \mathrm{t} \mathrm{ha}^{-1}$ with the 
dose of $147.02 \mathrm{~kg} \mathrm{ha}^{-1}$ of $\mathrm{K}_{2} \mathrm{O}$, an increase of $57 \%$ in relation to the control treatment, and $82 \%$ above the average of the state of Rondônia. These results are explained by the high requirement of the melancieira by potassium, nutrient extracted in greater quantity by the species, with increased demand after fruiting, when an intense translocation of the nutrient from vegetative organs to the fruit begins and the adequate supply is essential to ensure increased productivity and quality fruits (Grangeiro \& Cecílio Filho, 2005).

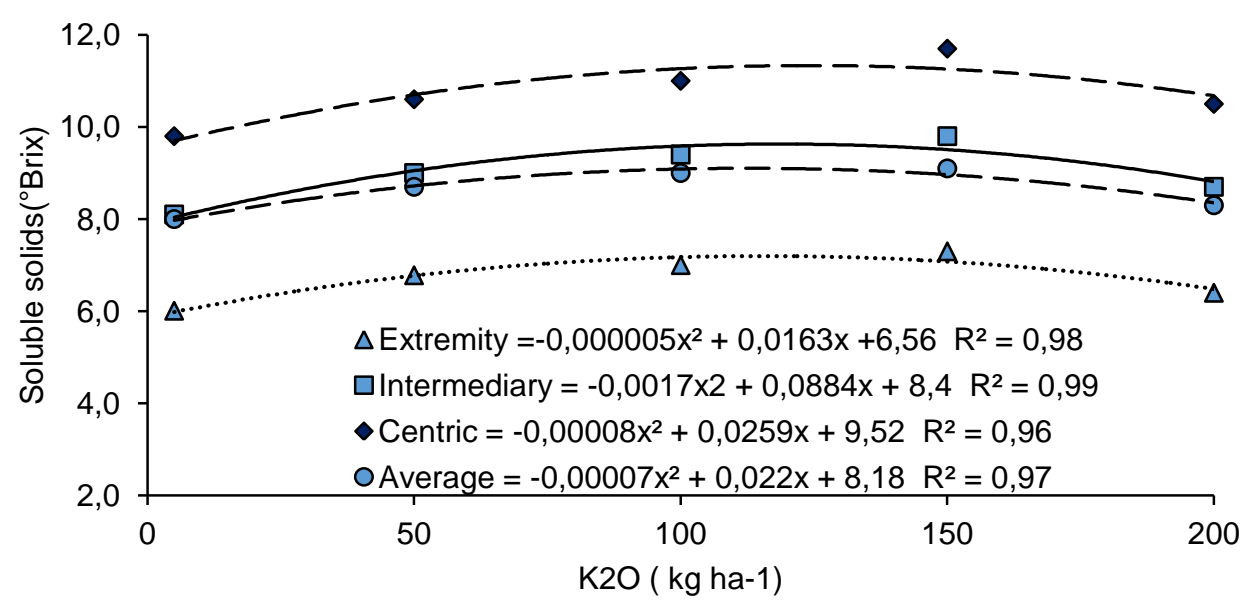

Figure 3. Total soluble solids ( ${ }^{\circ}$ Brix) content in four positions of watermelon fruit as a function of potassium doses.

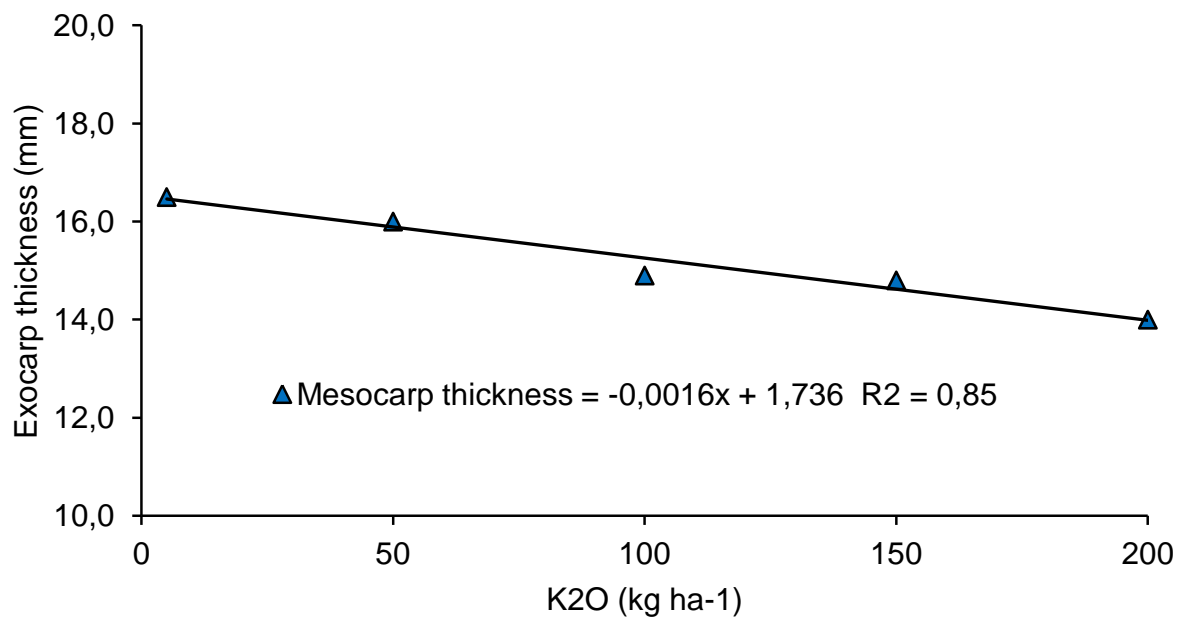

Figure 4. Thickness of the exocarp $(\mathrm{cm})$ of the watermelon as a function of potassium doses.

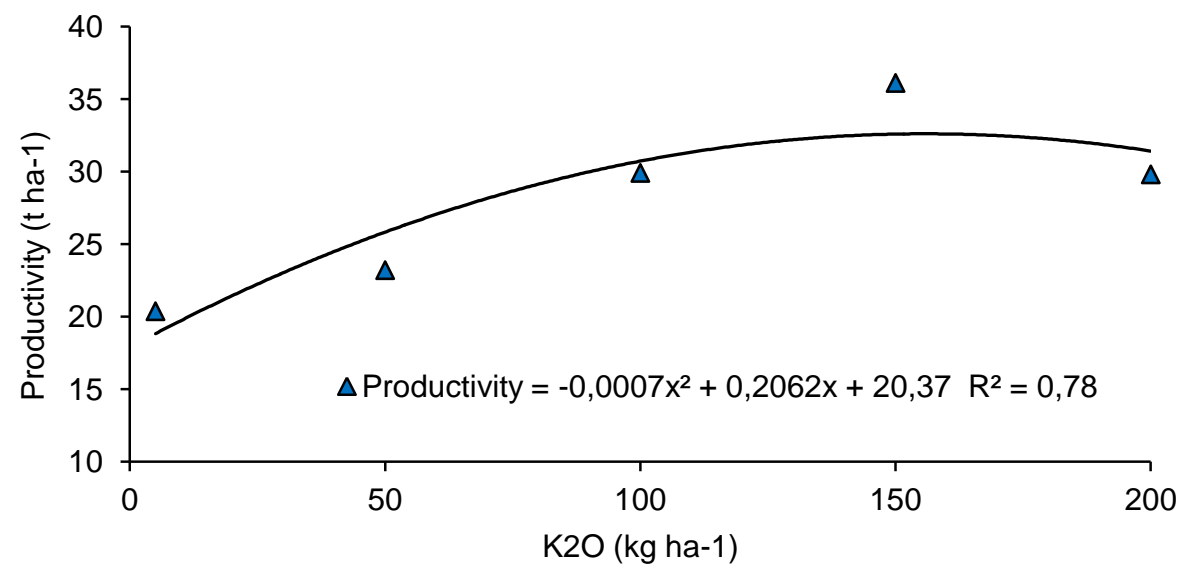

Figure 5. Productivity in total area of watermelon crop as a function of potassium fertilization dose. 
Moreover, and already mentioned, the increase in the availability of potassium in the soil promoted an increase in the number of fruits per plant, and consequently in the total productivity. The national average productivity is $22 \mathrm{t} \mathrm{ha}^{-1}$, considered low when compared to the main world producers (Dias \& Santos, 2019). The results obtained in this study are promising, $61.6 \%$ above the national average, and can be used as a reference for future recommendations of potassium fertilization in watermelon crops in the region.

The decrease in productivity with doses above $147.02 \mathrm{~kg} \mathrm{ha}^{-1}$ of $\mathrm{K}_{2} \mathrm{O}$ can be explained by the unbalance in the relationship between soil nutrients that can compete with potassium for the absorption sites in the root zone of plants. Because it is a monovalent cation $(\mathrm{K}+)$, potassium binds with less energy to soil colloids, being easily extracted and absorbed (Meyer et al., 2021), leading to a reduction in the absorption of other elements of greater valence, such as calcium and magnesium (Albuquerque et al., 2011), and thus promote a reduction in vegetative growth, and, consequently, productivity (Mengel \& Kirkby, 2001).

\section{Conclusions}

The number of fruits per plant increases linearly as a function of potassium doses applied in watermelon cultivation, however, doses above 150 $\mathrm{kg} \mathrm{ha}^{-1}$ of $\mathrm{K}_{2} \mathrm{O}$ make the fruits more fragile and susceptible to cracking in the field or in post-harvest due to the reduction in the thickness of the shell.

The contents of total soluble solids increase up to a dose of $157 \mathrm{~kg} \mathrm{ha}^{-1}$ of $\mathrm{K}_{2} \mathrm{O}$, improving the organoleptic quality of watermelon fruits, and in Amazonia, potassium fertilization with $147.02 \mathrm{~kg} \mathrm{ha}$ ${ }^{1}$ of $\mathrm{K}_{2} \mathrm{O}$ provides the production of $35.56 \mathrm{t}$ ha- 1 of watermelon, amount $61.6 \%$ above the national average and $82 \%$ above the average for the of Rondônia State.

\section{References}

ALBUQUERQUE, F.C.; SILVA, E.F.F.; ALBUQUERQUE FILHO, J.A.C.; NUNES, M.F.F.N. Crescimento e rendimento de pimentão fertirrigado sob diferentes lâminas de irrigação e doses de potássio. Revista Brasileira de Engenharia Agrícola e Ambiental, vol. 15, n. 7, p. 686-694, 2011. http://dx.doi.org/10.1590/S1415$\underline{43662011000700006}$

ALVARES, C.A.; STAPE, J.L.; SENTELHAS, P.C.; MORAES, J.L.G.; SPAROVEK, G. Köppen's climate classification map for Brazil. Meteorologische Zeitschrift, vol. 22, n. 6, p. 711-728, 2013. DOI: 10.1127/0941-2948 $/ 2013 / 0507$

BARROS, M.M.; ARAÚJO, W.F.; NEVES, L.T.B.C.; CAMPOS, A.J.; TOSIN, J.M. Produção e qualidade da melancia submetida a adubação nitrogenada. Revista Brasileira de Engenharia Agrícola e Ambiental, vol. 16, n. 10, p. 1078-1084, 2012. https://doi.org/10.1590/S141 5$\underline{43662012001000007}$

BLEINROTH, E.W. Determinação do ponto de colheita. In: NETTO, A.G. (ed.). Melão para exportação:
Procedimentos de colheita e pós colheita. Brasília: MAARA/FRUPEX. p. 11-21, 1994.

DIAS, R. de; SANTOS, J.S. Panorama nacional da produção de melancia. Embrapa Semiárido - Artigo em periódico indexado (ALICE), 2019. Disponível em: https://ainfo.cnptia.embrapa.br/digital/bitstream/item1962 37/1/Rita-2019.pdf. Acesso em: 15 jun. 2020.

DIAS, R.C.S.; RESENDE, G.M. Embrapa: Sistema de Produção de Melancia. Embrapa Semiárido, 6. 2010. Disponível em: https://sistemasdeproducao.cnptia.em brapa.br/FontesHTML/Melancia/SistemaProducaoM elancia/index.html. Acesso em: 21 out. 2018.

FAOSTAT, Divisão de Estatísticas da Organização das Nações Unidas para a Agricultura e Alimentação (2018). Disponível em: http://www.fao.org/faostat/em /\# data. Acesso: 27 jun. 2020.

GRANGEIRO, L.C; CECÍlIO FILHO, A.B. Acúmulo e exportação de nutrientes pela melancia sem sementes, híbrido Shadow. Científica, vol. 33, n. 1, p. 69-74, 2005.

GURGEL, M.T.; UYEDA, C.A.; GHEYI, H.R.; OLIVEIRA, F.H.T.; FERNANDES, P.D.; SILVA, F.V. Crescimento de meloeiro sob estresse salino e doses de potássio. Revista Brasileira de Engenharia Agrícola e Ambiental, vol.14, n.1, p. 3-10, 2010. http://dx.doi.org/10.1590/S14 15$\underline{43662010000100001}$

IBGE, Instituto Brasileiro de Geografia e Estatística. Produção agrícola municipal. 2019. Disponível em: https://sidra.ibge.gov.br/tabela/5457\#resultado. Acesso em: 14 ago. 2021.

KOMANE, B.; VERMAAK, I.; KAMATOU, G.; SUMMERS, B.; VILJOEN, A. The topical efficacy and safety of Citrullus lanatus seed oil: A short-term clinical assessment. South African Journal of Botany, vol. 112, p. 466-473, 2017. https://doi.org/10.1016/j.sajb.2017.0 6.028

KUMAR, P.; PANDEY, S.K.; SINGH, B.P.; SINGH, S.V.; KUMAR, D. Influence of source and time of potassium application on potato growth, yield, economics and crisp quality. Potato Research, vol. 50, n. 1, p. 1-13, 2007. DOI: $10.1007 / \mathrm{s} 11540-007-9023-8$

MENGEL, K.; KIRKBY, E.A. Principles of Plant Nutrition. 5 ed. New Jersey: Kluwer Academic Publishers, 2001. 807 p.

Meyer. G.; Bell M.J.; Lombi, E.; Doolette, C.L.; Brunetti, G.; Novotny, E.H.; Klysubun, W.; Zhang Y, Kopittke PE. Phosphorus speciation in the fertosphere of highly concentrated fertilizer bands. Geoderma. vol. 403, 115208. 2021. https://doi.org/10.1016/i.geoderma.2021. $\underline{115208}$

RAIJ, B.V. Potássio: necessidade e uso na agricultura moderna. Piracicaba: POTAFOS. 1990. 45 p.

RIBEIRO, A.C.; GUIMARÃES, P.T.G.; VENEGAS, V.H.A. Recomendações para uso de corretivos e fertilizantes em Minas Gerais. Viçosa: CFSEMG, 1999. 359 p.

SANTOS, H.G. dos; JACOMINE, P.K.T.; ANJOS, L.H. C. dos; OLIVEIRA, V.A. de; LUMBRERAS, J.F.; COELHO, M.R.; ALMEIDA, J.A. de; ARAUJO FILHO, J.C. de OLIVEIRA, J.B. de; CUNHA, T.J.F. Sistema Brasileiro de 
Classificação de Solos. 5. ed. rev. e ampl. Brasília, DF: Embrapa, 2018. 356 p.

SILVA, M.D.C.; SILVA, T.J.A.; BONFIM-SILVA, E.M.; FARIAS, L.N. Características produtivas e qualitativas de melão rendilhado adubado com nitrogênio e potássio. Revista Brasileira de Engenharia Agrícola e Ambiental. vol. 18, n.6, p. 581-587, 2014. https://doi.org/10.1590/S $\underline{1415-43662014000600003}$

SILVA, V.F.A.; MELO, N.C.; GALVÃO, J.R.; SILVA, D.R.; PEREIRA, W.V.P.; RODRIGUES, F.H.S. Produção de melancia e teores de sólidos solúveis totais em resposta a adubação nitrogenada e potássica. Revista Brasileira de Agricultura Irrigada, vol. 9. n. 3, p.136-144, 2015. DOl: $\underline{10.7127 / \text { rbai.v9n300299 }}$

SOUZA, F.F.; ROSA NETO, C.; TEIXEIRA, C.A.D.; FERNANDES, C.F.; GAMA, F. de C.; FRANDSEN, J.E.; COSTA, J.N.M.; QUEIROZ, M.A. de; DIAS, R. de. C.S.; VIZA, R.; HOLANDA FILHO, Z.F. Cultivo da melancia em Rondônia. Porto Velho: Embrapa Rondônia. 2008.103 p.

TAIZ, L.; ZEIGER, E. Fisiologia vegetal. 5.ed. Porto Alegre: $\quad$ Artemed, $2013 . \quad 952 \quad$ p. 